\title{
An aluminium battery operating with an aqueous electrolyte
}

\author{
A. Holland ${ }^{1}$ - R. D. Mckerracher ${ }^{1} \cdot$ A. Cruden ${ }^{1} \cdot$ R. G. A. Wills ${ }^{1}$ (D) \\ Received: 4 August 2017 / Accepted: 17 January 2018 / Published online: 2 February 2018 \\ (c) The Author(s) 2018. This article is an open access publication
}

\begin{abstract}
Aluminium is an attractive active material for battery systems due to its abundance, low cost, a gravimetric energy density of $2.98 \mathrm{Ah} \mathrm{g}^{-1}$ (c.f. lithium 3.86 $\mathrm{Ah} \mathrm{g}^{-1}$ ) and a volumetric energy density of $8.04 \mathrm{Ah} \mathrm{cm}^{-3}$ (c.f. lithium $2.06 \mathrm{Ah} \mathrm{cm}^{-3}$ ). An aqueous electrolyte-based aluminium-ion cell is described using $\mathrm{TiO}_{2}$ nanopowder as the negative electrode, $\mathrm{CuHCF}$ (copper-hexacyanoferrate) as the positive electrode and an electrolyte consisting of $1 \mathrm{~mol} \mathrm{dm}^{-3} \mathrm{AlCl}_{3}$ and $1 \mathrm{~mol} \mathrm{dm}^{-3} \mathrm{KCl}$. Voltammetric and galvanostatic analyses have shown that the discharge voltage is circa $1.5 \mathrm{~V}$. Both a single-cell and 2-cell battery are demonstrated using $10 \mathrm{~cm}^{2}$ electrodes and 126 and $256 \mathrm{mg}$ total active material for the 1-cell and 2-cell batteries, respectively. The single cell exhibits an energy density of circa $15 \mathrm{~mW} \mathrm{~h} \mathrm{~g}^{-1}$ (combined positive and negative electrode masses) at a power density of $300 \mathrm{~mW} \mathrm{~g}^{-1}$ with energy efficiency remaining above $70 \%$ for over 1750 cycles. Initial characterisation shows that charge storage is due to the presence of $\mathrm{Al}^{3+}$. Cell capacity is circa $10 \mathrm{~mA} \mathrm{~h} \mathrm{~g}$ and operates with a discharge voltage of circa $1.5 \mathrm{~V}$ (efficiency $>80 \%$ at $20 \mathrm{C}$ charge/discharge rate).
\end{abstract}

\section{Graphical Abstract}

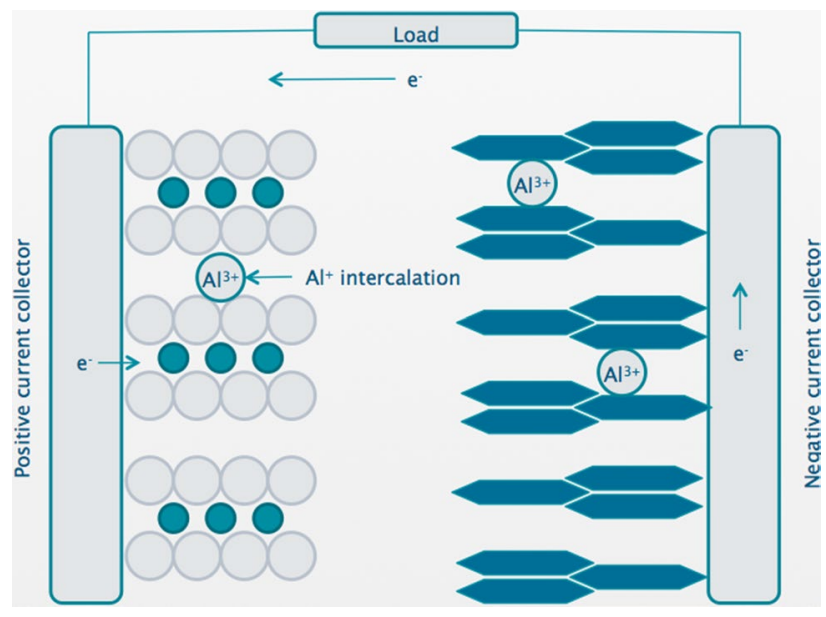

Keyword Aqueous aluminium ion battery

\section{Introduction}

R. G. A. Wills

rgaw@soton.ac.uk

1 Faculty of Engineering and the Environment, University of Southampton, Highfield, Southampton SO17 1BJ, UK

The consumption of renewable energy, excluding hydropower, has grown almost exponentially over the past 20 years [1]. Most of this growth has come in the form of distributed solar PV and wind power which can cause a number of problems for electricity grids. For example, cloud cover can cause output from solar PV plants to be subject to 
large voltage and power fluctuations. This can be alleviated through use of low energy but high power, high cycle life and fast response energy storage systems [2]. Given suitable electrode materials, the high conductivity of aqueous electrolytes mean aqueous intercalation batteries may be capable of providing these characteristics in addition to being safe, non-toxic and potentially low-cost when compared to nonaqueous systems, such as ionic liquids. This communication reports on the construction and testing of a fully functional aqueous Al-ion cell. It should be noted that the majority of $\mathrm{Al}$-ion research focusses on room temperature ionic liquid electrolyte systems (RTILs) theoretically allowing the utilisation of aluminium metals high capacity through reversible deposition [3-10]. The primary research aim becomes the identification of positive electrode materials that will not severely limit cell capacity. Table 1 provides an overview of RTIL-based Al-ion systems reported in the literature to date. Cycle life varies from just 50 to 7500 . Applied currents also vary considerable between reported electrodes, from 12 up to $5000 \mathrm{~mA} \mathrm{~g}^{-1}$. The majority of studies use $\mathrm{AlCl}_{3} / \mathrm{EMICl}$ (1-ethyl-3-methylimidazolium chloride) or $\mathrm{AlCl}_{3} / \mathrm{BMICl}$ (1-butyl-3-methylimidazolium chloride) as the electrolyte. Given a suitable positive electrode, a high capacity and energy density cell could be constructed. The best-performing cell to date, with a natural graphite positive electrode, has achieved a capacity of c.a. $100 \mathrm{~mA} \mathrm{~h} \mathrm{~g}^{-1}$ when cycled at $198 \mathrm{~mA} \mathrm{~g}^{-1}$. However, the expense and corrosiveness of RTILs are significant disadvantages of such a battery system.

The use of water as solvent for an aluminium salt has the potential to provide a cheap, inherently safe and more conductive electrolyte system compared to RTILs. Table 2 summarises the literature available for the aqueous aluminium ion battery. Only three electrode materials, anatase $\mathrm{TiO}_{2}$, copper-hexacyanoferrate (CuHCF), and aerogel $\mathrm{V}_{2} \mathrm{O}_{5}$, have been shown to allow the reversible intercalation of $\mathrm{Al}^{3+}$ in aqueous electrolytes [11-16]. The most successful negative electrode was black-anatase $\mathrm{TiO}_{2}$, reported by $\mathrm{He}$ et al. [11] that produced a high capacity of $270 \mathrm{mAh} \mathrm{g}^{-1}$, in $1 \mathrm{~mol}$ $\mathrm{dm}^{-3} \mathrm{Al}\left(\mathrm{NO}_{3}\right)_{3}$, although only 300 cycles were reported. $\mathrm{CuHCF}$ was shown by Liu et al. to give a capacity of 41 $\mathrm{mAh} \mathrm{g}^{-1}$ at $400 \mathrm{~mA} \mathrm{~g}^{-1}$ in $0.5 \mathrm{~mol} \mathrm{dm}^{-3} \mathrm{Al}_{2}\left(\mathrm{SO}_{4}\right)_{3}$ [12]. A capacity fade of $41 \%$ was measured over 1000 cycles. $\mathrm{CuHCF}$ has also been tested as a positive electrode for an Al-ion cell containing organic electrolyte but reversible capacity was low at 5-14 $\mathrm{mA} \mathrm{h} \mathrm{g}^{-1}$ [13]. However, CuHCF, along with a number of other hexacyanoferrates, has also been shown to function as positive electrodes in other aqueous electrolytes containing $\mathrm{K}^{+}, \mathrm{Na}^{+}, \mathrm{Mg}^{2+}$ or $\mathrm{Zn}^{2+}$ [14-17]. Specific capacities of approximately $50-60 \mathrm{~mA} \mathrm{~h} \mathrm{~g}^{-1}$ are often reported. It should be noted that the capacities quoted regarding aqueous $\mathrm{Al}$-ion cells are for individual electrode materials and not operational cells, where the positive and negative materials must be jointly considered. Furthermore, these studies have been limited to half-cell analysis and not operated in a battery configuration. In this paper, we discuss the electrochemical performance of a combined cell and a two-cell battery, demonstrating an operational system based on an aqueous electrolyte containing $\mathrm{Al}^{3+}$.

\section{Experimental procedure}

Anatase- $\mathrm{TiO}_{2}$ nanopowder $(<25 \mathrm{~nm})$ was used as received from Sigma Aldrich. Electrode inks were prepared through the addition of $\mathrm{TiO}_{2}$, carbon black (CB), and Nafion binder, in the ratio 9:0.5:0.5 by wt $\%$. The positive electrode consisted of CuHCF, carbon black (CB), and Nafion binder in the ratio 8:1:1. Propanol was added to form inks of suitable viscosity (approximately 3:1 propanol:active material) and mixed at $5000 \mathrm{rpm}$ for $30 \mathrm{~min}$ using Silverson shear blade mixer. The resulting inks were coated onto Sigracell PV10 carbon polymer current collectors from SGL and left to dry in ambient conditions.

$\mathrm{CuHCF}$ was prepared through a standard precipitation method. $1.5 \mathrm{~mol} \mathrm{dm}{ }^{-3}$ solution $\mathrm{Cu}\left(\mathrm{NO}_{3}\right)_{2}$ was added to $1 \mathrm{~mol} \mathrm{dm}^{-3}$ solution of $\mathrm{K}_{3}\left[\mathrm{Fe}(\mathrm{CN})_{6}\right]$ and stirred for a minimum of $2 \mathrm{~h}$ at room temperature. The precipitate was centrifuged and washed five times before drying in air at $80^{\circ} \mathrm{C}$ and grinding to form $\mathrm{CuHCF}$ powder.

Standard 3-electrode glass cells were used for cyclic voltammetry (CV) to characterise the electrochemical activity of $\mathrm{TiO}_{2}$ in aqueous electrolytes. A saturated calomel electrode (SCE) was used as the reference electrode and a platinum wire as the counter electrode. An Ivium multichannel electrochemical analyser was used for CV scans. The galvanostatic performance of both electrodes was investigated in full cells through oversizing of the opposing electrode so that the cell capacity was only dictated by the electrode under investigation. An SCE reference electrode was used, in connection with a National Instruments data acquisition module, for voltage measurements of individual electrodes when being operated in a full cell, see Fig. 1. For these 2-electrode experiments, capacities of 16 and $50 \mathrm{~mA}$ $\mathrm{h} \mathrm{g}^{-1}$ were assumed for $\mathrm{TiO}_{2}$ and $\mathrm{CuHCF}$, respectively, such that a $20 \mathrm{C}$ cycle rate corresponds to $333 \mathrm{~mA} \mathrm{~g}^{-1}$ for $\mathrm{TiO}_{2}$ and $1000 \mathrm{~mA} \mathrm{~g}^{-1}$ for CuHCF. A balanced cell, where the $\mathrm{TiO}_{2}$-electrode capacity was approximately equal to CuHCFelectrode capacity, used $10 \mathrm{~cm}^{2}$ of each active material on carbon polymer, separated by an electrolyte cavity, as shown in Fig. 1. Positive and negative electrode loadings were 3.8 and $8.5 \mathrm{mg} \mathrm{cm}^{-2}$ for the final cell, constituting larger format electrodes than previously reported. Electrode loadings for the 2-cell battery were 3.6 and $9.2 \mathrm{mg} \mathrm{cm}^{-2}$. When operated as a unit cell, the positive electrode (CuHCF) acted as the working electrode for the Ivium analyser, with the negative 


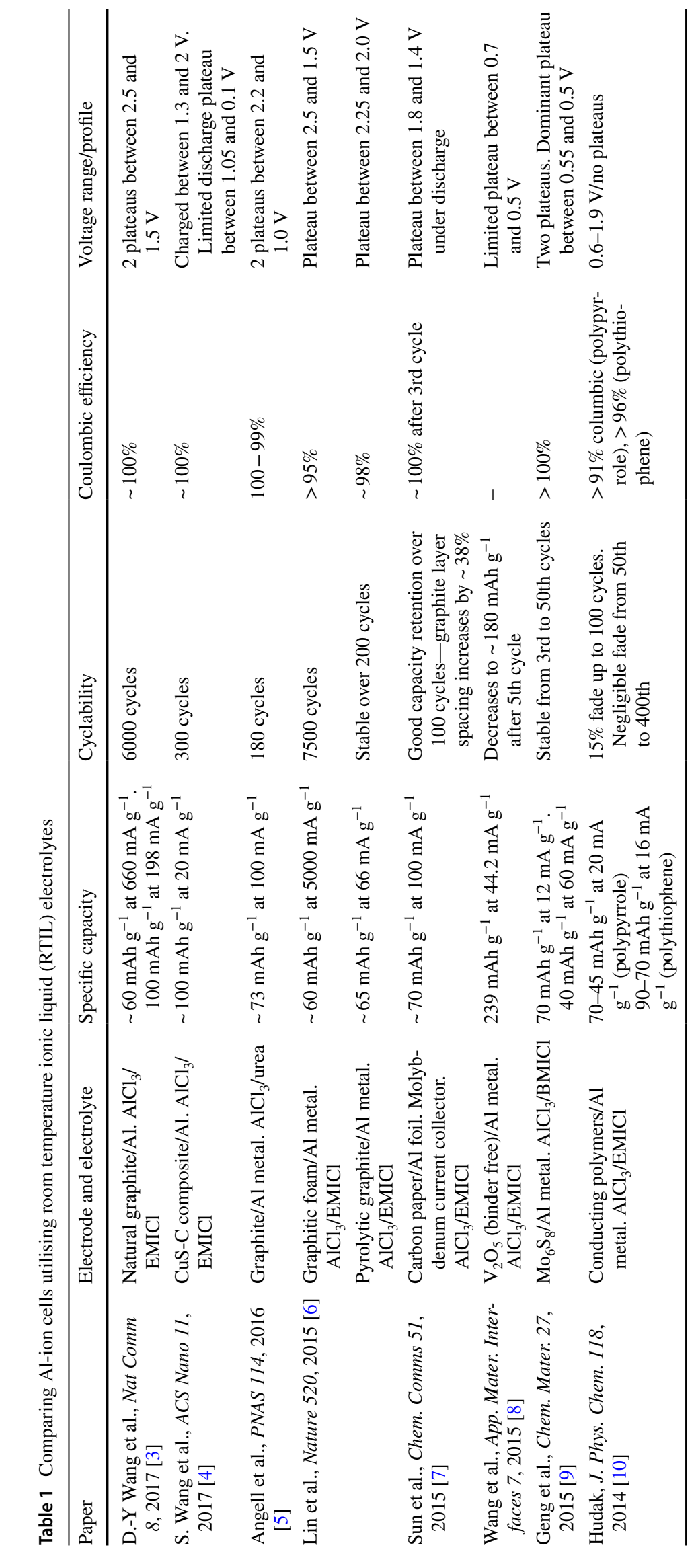




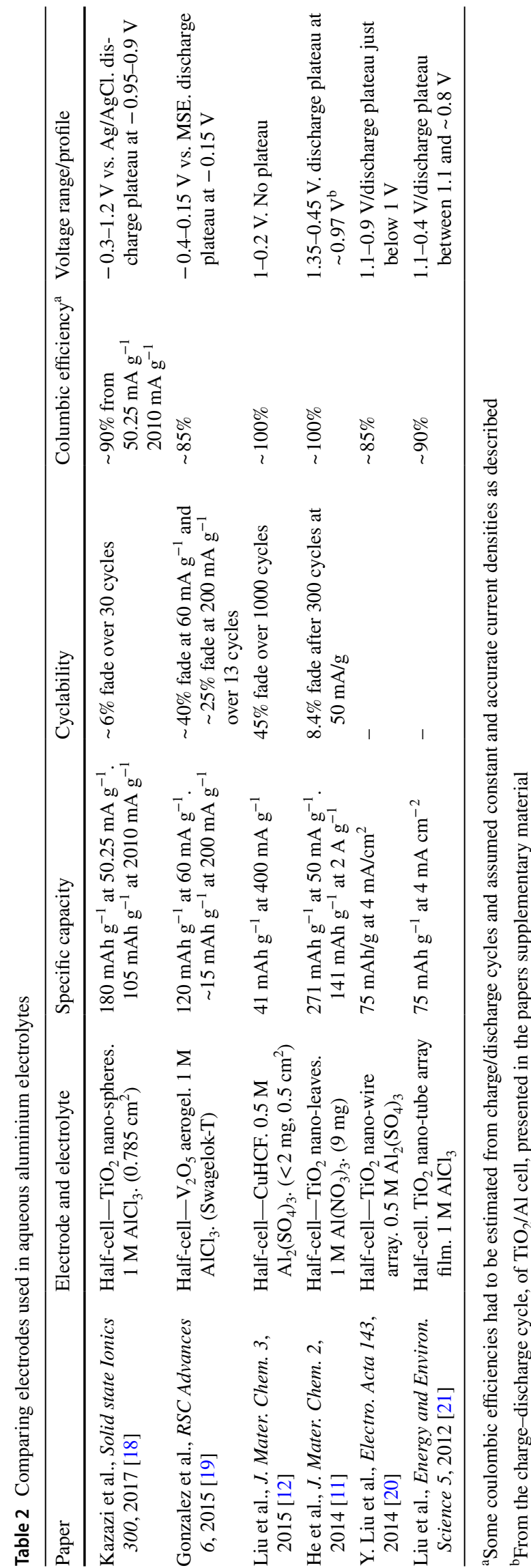

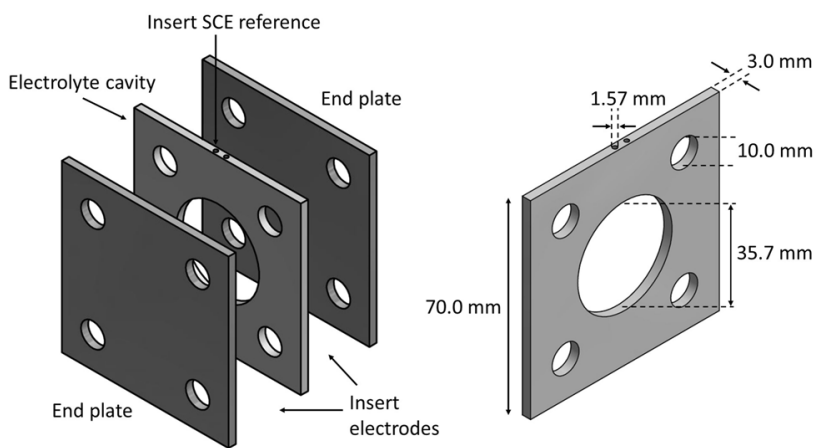

Fig. 1 Schematic of the cell configuration used for the aqueous Alion cell. End plates were made of stainless steel and electrolyte cavity insert of PEEK

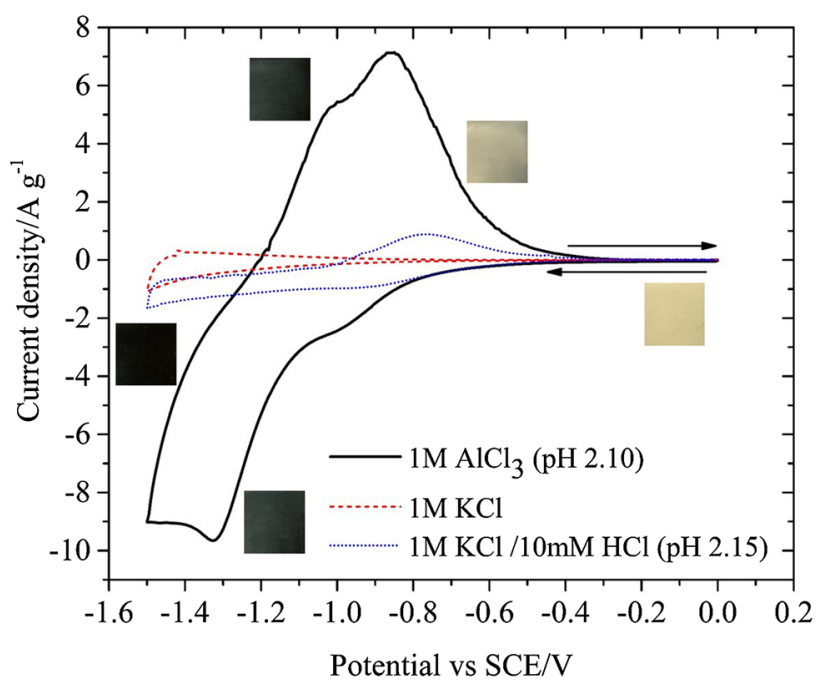

Fig. 2 Cyclic voltammetry of a $\mathrm{TiO}_{2}$ electrode in $1 \mathrm{~mol} \mathrm{dm}{ }^{-3} \mathrm{AlCl}_{3}$ as well as 'blank' electrolytes consisting of $1 \mathrm{~mol} \mathrm{dm}^{-3} \mathrm{KCl}$ and $1 \mathrm{~mol} \mathrm{dm}^{-3} \mathrm{KCl}$ with $10 \mathrm{mmol} \mathrm{dm}{ }^{-3} \mathrm{HCl}$. A scan rate of $10 \mathrm{mV} \mathrm{s}^{-1}$ was used

electrode $\left(\mathrm{TiO}_{2}\right)$ being connected to the counter and reference electrode terminals.

Neutron diffraction analysis was obtained using the GEM diffractometer via GEM Xpress operated at ISIS under project numbers (RN 1690193 and 1690194). Data sets were interpreted by the facility.

\section{Results and discussion}

A cyclic voltammogram was obtained at a $\mathrm{TiO}_{2}$ electrode (cell anode) in aqueous $1 \mathrm{~mol} \mathrm{dm}^{-3} \mathrm{AlCl}_{3}, 1 \mathrm{~mol} \mathrm{dm}^{-3} \mathrm{KCl}$, and $1 \mathrm{~mol} \mathrm{dm}^{-3} \mathrm{KCl} / 10 \mathrm{mmol} \mathrm{dm}^{-3} \mathrm{HCl}$. The potential was swept from 0 to $-1.5 \mathrm{~V}$ vs. SCE before returning to $0 \mathrm{~V}$. A constant sweep rate of $10 \mathrm{mV} \mathrm{s}^{-1}$ was maintained 
throughout. Figure 2 presents the voltammogram with overlaying photographic images of the electrode surface at key potentials. Towards negative potentials, a reduction wave associated with $\mathrm{Al}^{3+}$ interacting with the $\mathrm{TiO}_{2}$ electrode commences at circa $-0.8 \mathrm{~V}$ with an associated peak at circa $-1.31 \mathrm{~V}$. The current peaks at $-9.7 \mathrm{~A} \mathrm{~g}^{-1}$. On the reverse sweep, an oxidation wave is observed, with a peak of $7.2 \mathrm{~A}$ $\mathrm{g}^{-1}$, at $-0.85 \mathrm{~V}$. Both reduction and oxidation waves have secondary peaks, at circa $0.98 \mathrm{~V}$ and circa $-1.05 \mathrm{~V}$ respectively, indicating more than one reaction process associated with the $\mathrm{TiO}_{2} / \mathrm{Al}^{3+}$ interaction. In $1 \mathrm{~mol} \mathrm{dm}{ }^{-3} \mathrm{AlCl}_{3}$, electrolyte stability at the electrode is good, with the onset of $\mathrm{H}_{2}$ evolution not yet visible at $-1.5 \mathrm{~V}$. An electrolyte containing $1 \mathrm{~mol} \mathrm{dm}^{-3} \mathrm{KCl}$ gave rise to no discernible redox activity, however, demonstrating that the redox phenomena are linked to the presence of $\mathrm{Al}^{3+}$ in the electrolyte solution. With the addition of $\mathrm{HCl}$, small reduction and oxidation peaks, of approximately $1 \mathrm{~A} \mathrm{~g} \mathrm{~g}^{-1}$, became apparent at roughly -0.9 and $-0.8 \mathrm{~V}$, respectively. This suggests an inherent response from anatase $\mathrm{TiO}_{2}$ in acidic aqueous electrolyte, which is an order of magnitude smaller in capacity than the response obtained in the presence of $\mathrm{Al}^{3+}$.

Photographic images were periodically taken, during a scan of a $\mathrm{TiO}_{2}$-only electrode, and have been overlaid at the appropriate potentials in Fig. 2. These images graphically show the charge/discharge process at the negative electrode. In the charged state, the electrode is dark blue-grey, while in the discharged state the electrode almost returns to the original white colour associated with $\mathrm{TiO}_{2}$. These changes could be attributed to the reduction of $\mathrm{Ti}^{4+}$ to $\mathrm{Ti}^{3+}$ via four possible processes: $\mathrm{Al}^{3+}$ surface adsorption, $\mathrm{Al}^{3+}$ intercalation, $\mathrm{H}^{+}$surface adsorption and/or $\mathrm{H}^{+}$intercalation. Further mechanistic studies are planned to fully elucidate the processes involved.

The effect of acidity on the response is shown in Fig. 3. Anodic peak currents are seen to decrease with increasing acidity, while cathodic peaks became decreasingly prominent, due to hydrogen evolution. This suggests that increasing the acidity of the electrolyte would be detrimental to cell performance. In conjunction with Fig. 1, it can be concluded that the redox activity of anatase $\mathrm{TiO}_{2}$ is primarily due to the presence of $\mathrm{Al}^{3+}$ and not protons.

Neutron diffraction analysis of the negative electrode was carried out at ISIS using the General Materials Diffractometer (GEM). Two runs were undertaken: 79453 (freshly prepared electrode) and 79454 (electrode after charge/discharge cycling). The results showed a very good fit to a $\mathrm{TiO}_{2}$ structure with the two data sets having the following lattice parameters:79453 a @ 3.7707(9), b @ 3.7706(10), c @ 9.4631(23), and 79454 a @ 3.7697(9), b @ 3.7695(10), c @ 9.4589(24). That is a difference of 0.001 Angstroms in a, 0.002 in $b$ and 0.004 in c. This is a very slight shift in lattice parameters between an unused electrode and one that has

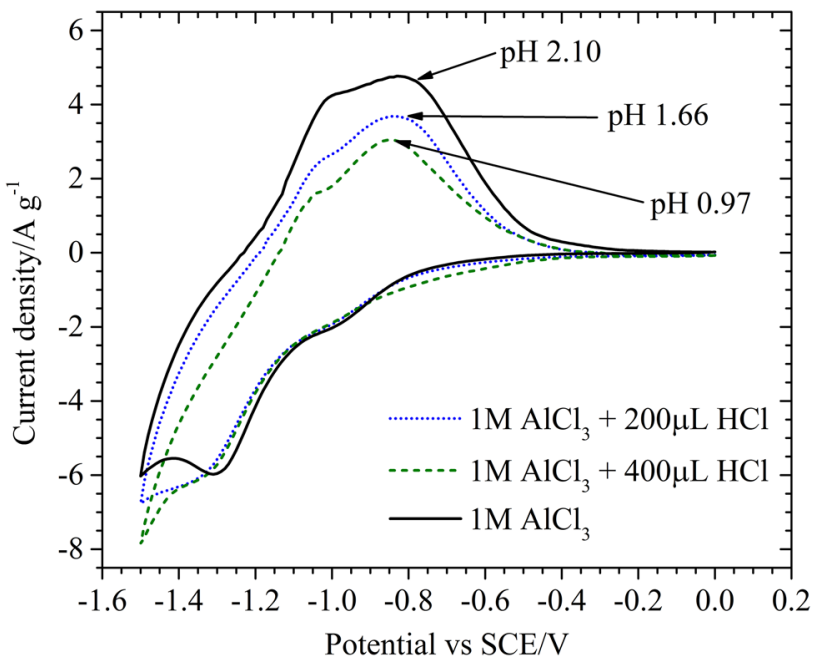

Fig. 3 Cyclic voltammetry of a $\mathrm{TiO}_{2}$ electrode in $1 \mathrm{~mol} \mathrm{dm}{ }^{-3} \mathrm{AlCl}_{3}$ electrolytes of increasing acidity. A scan rate of $10 \mathrm{mV} \mathrm{s}^{-1}$ was used

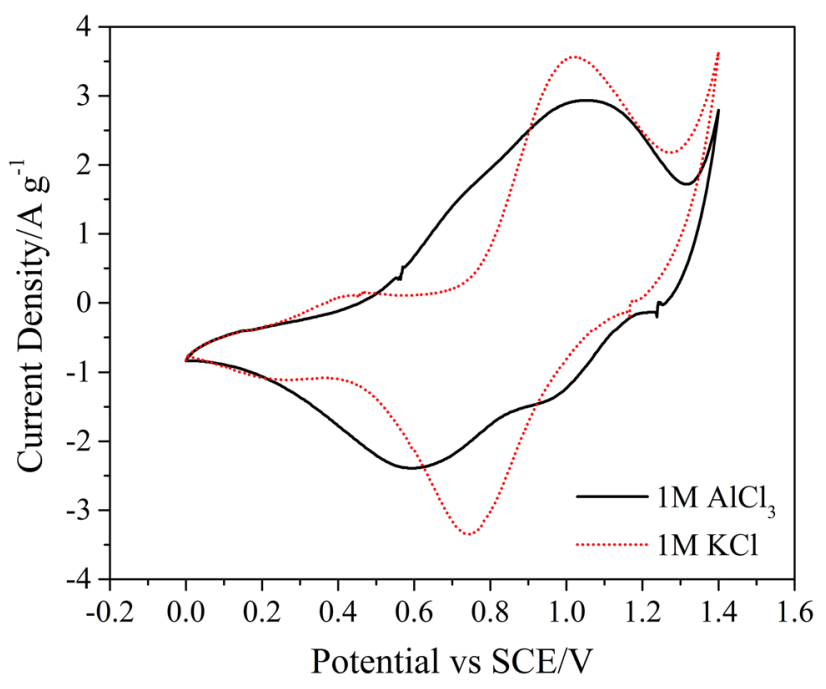

Fig. 4 Cyclic voltammetry of CuHCF at $20 \mathrm{mV} \mathrm{s}^{-1}$ in $1 \mathrm{~mol} \mathrm{dm}^{-3}$ $\mathrm{AlCl}_{3}$ and $1 \mathrm{~mol} \mathrm{dm}^{-3} \mathrm{KCl}$. An SCE and Pt-wire were used as reference and counter electrodes

been exposed to $\mathrm{Al}^{3+}$ in a battery environment. This represents a shift higher than the measured error (by an order of magnitude in a, by a factor of 2 in $b$ and c) and so may be significant. While this lattice expansion may be evidence of $\mathrm{Al}^{3+}$ intercalation, further analysis is required on in situ electrodes over a range of states of charge to validate the mechanism.

Cyclic voltammograms were obtained at $\mathrm{CuHCF}$ electrodes (cell cathode) in $1 \mathrm{~mol} \mathrm{dm}^{-3} \mathrm{AlCl}_{3}$ and $1 \mathrm{~mol} \mathrm{dm}^{-3}$ $\mathrm{KCl}$. The voltammetric response is presented in Fig. 4. In $1 \mathrm{~mol} \mathrm{dm}^{-3} \mathrm{AlCl}_{3}$, broad reduction and oxidation peaks are visible at 0.6 and $1.05 \mathrm{~V}$, respectively. Broad shoulders are 
also observed during the anodic and cathodic sweeps, centred on 0.7 and $1.0 \mathrm{~V}$, respectively. Bulk oxygen evolution was observed at potentials more positive than $1.3 \mathrm{~V}$ vs. SCE. $1 \mathrm{~mol} \mathrm{dm}^{-3} \mathrm{KCl}$ produces sharper peaks at 0.74 and $1.0 \mathrm{~V}$, suggesting more facile insertion of $\mathrm{K}^{+}$than $\mathrm{Al}^{3+}$. The use of a mixed $\mathrm{Al}^{3+} / \mathrm{K}^{+}$electrolyte may therefore provide favourable cell operation where $\mathrm{TiO}_{2}$ and $\mathrm{CuHCF}$ are utilised as the negative and positive electrodes.

With redox activity of $\mathrm{TiO}_{2}$ and $\mathrm{CuHCF}$ in $\mathrm{Al}^{3+}$ containing electrolyte confirmed, the performance of these electrodes was tested in aqueous Al-ion cells. Cells were limited by a single electrode by ensuring the capacity of the opposite electrode was considerably larger. $\mathrm{TiO}_{2}$ was galvanostatically charged to a specific capacity at a current density of $333 \mathrm{~mA} \mathrm{~g}^{-1}$. Figure 5 shows the discharge capacity and coulombic efficiency of $\mathrm{TiO}_{2}$ as a function of charge input. Above a $16-17 \mathrm{~mA} \mathrm{~h} \mathrm{~g}^{-1}$ charge input, there is limited increase in discharge capacity while the associated coulombic efficiency drops dramatically from $>80 \%$ to $<50 \%$ at beyond $30 \mathrm{mAh} \mathrm{g}^{-1}$. Both $\mathrm{TiO}_{2}$ - and $\mathrm{CuHCF}-$ limited 2-electrode cells were then cycled at a charge and discharge current density of $333 \mathrm{~mA} \mathrm{~g}^{-1}$ for 1000 cycles. The results are summarised in Table $3 . \mathrm{TiO}_{2}$ produced a capacity of $14.5 \mathrm{~mA} \mathrm{~h} \mathrm{~g}^{-1}$ which decreased by $\sim 7 \%$ after 1000 cycles (c.f. $45 \%$ capacity fade over 1000 cycles previously reported in the literature [13]) demonstrating that while the capacity is initially low, the electrode material and architecture are robust. The $\mathrm{TiO}_{2}$ electrode was cycled. The capacity is considerably lower than would be expected from an intercalation electrode. The theoretical capacity of $\mathrm{TiO}_{2}$ is $335 \mathrm{~mA} \mathrm{~h} \mathrm{~g}^{-1}$ assuming intercalation proceeds according to reaction 1 [11], where $0<x<1 / 3$ since charge capacity is likely limited by the $\mathrm{Ti}^{4+} / \mathrm{Ti}^{3+}$ couple. This suggests

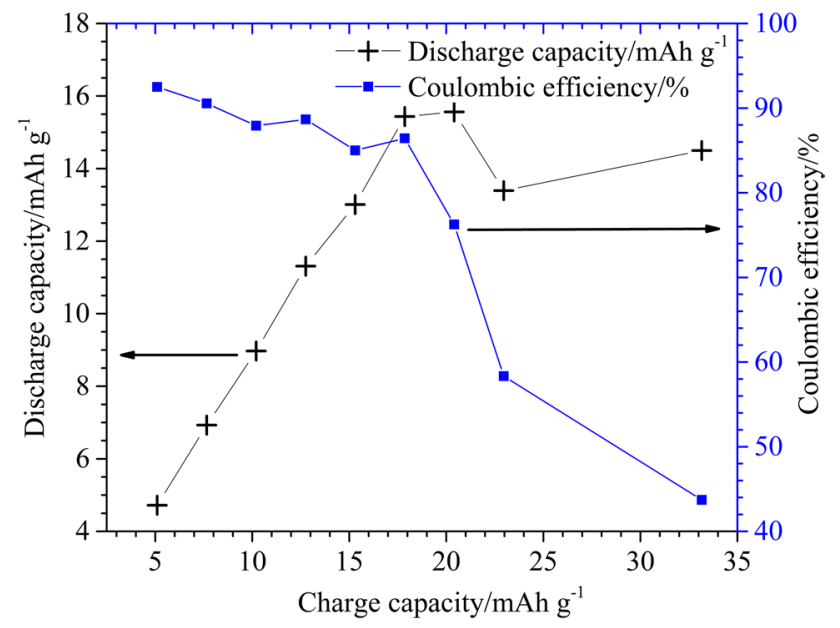

Fig. 5 The discharge capacity and coulombic efficiency of a $\mathrm{TiO}_{2}$ electrode as a function of charge capacity when cycled at $333 \mathrm{~mA} \mathrm{~g}^{-1}$ in $1 \mathrm{~mol} \mathrm{dm}^{-3} \mathrm{AlCl}_{3} / 1 \mathrm{~mol} \mathrm{dm}{ }^{-3} \mathrm{KCl}$
Table 3 Summary of performance of $\mathrm{TiO}_{2}$ - and CuHCF- limited cells cycled in $1 \mathrm{~mol} \mathrm{dm}^{-3} \mathrm{AlCl}_{3}$ and $1 \mathrm{~mol} \mathrm{dm}^{-3} \mathrm{KCl}$ at a current density of $333 \mathrm{~mA} \mathrm{~g}^{-1}$ (based on the mass of the limiting electrode)

\begin{tabular}{lll}
\hline & $\mathrm{TiO}_{2}\left(333 \mathrm{~mA} \mathrm{~g}^{-1}\right)$ & $\mathrm{CuHCF}\left(1000 \mathrm{~mA} \mathrm{~g}^{-1}\right)$ \\
\hline Capacity & $14 \mathrm{~mA} \mathrm{~h} \mathrm{~g}^{-1}$ & $50 \mathrm{~mA} \mathrm{~h} \mathrm{~g}$ \\
Average discharge & $-0.65 \mathrm{~V}^{-1}$ vs. SCE & $0.70 \mathrm{~V} \mathrm{vs.} \mathrm{SCE}$ \\
$\quad$ voltage & & \\
Coulombic efficiency & $84-80 \%$ & $92-94 \%$ \\
Energy efficiency & $72-66 \%$ & $66 \%$ \\
Cycled to & $>1000$ & $>1000$ \\
\hline
\end{tabular}

$\mathrm{Al}^{3+}$ surface adsorption to be the most likely charge storage mechanism.

$\mathrm{TiO}_{2}+x \mathrm{Al}^{3+}+3 x e^{-} \leftrightarrow \mathrm{Al}_{x} \mathrm{TiO}_{2}$

The coulombic efficiency of $\mathrm{TiO}_{2}$ remained around $80 \%$ while the energy efficiency decreased by only $5 \%$ from a maximum of $71 \%$. The more negative voltage profile in Fig. 6 corresponds to the $\mathrm{TiO}_{2}$ electrode, vs. SCE, during cycling. A very small initial voltage hysteresis shows that the electrode should be capable of discharge at higher rates; however, coulombic efficiency is clearly low and may be indicative of a simultaneous self-discharge process.

Galvanostatic cycling of $\mathrm{CuHCF}$ at $1000 \mathrm{~mA} \mathrm{~g}^{-1}$ produced a capacity of $\sim 50 \mathrm{mAh} \mathrm{g}^{-1}$ throughout $>1000$ cycles. Coulombic efficiency was $97.2 \%$ after 20 cycles and decreased to $94 \%$; energy efficiency of the CuHCF-limited cell remained at $\sim 66 \%$ over $>1000$ cycles, which surpasses the previously reported cycling of electrodes incorporating

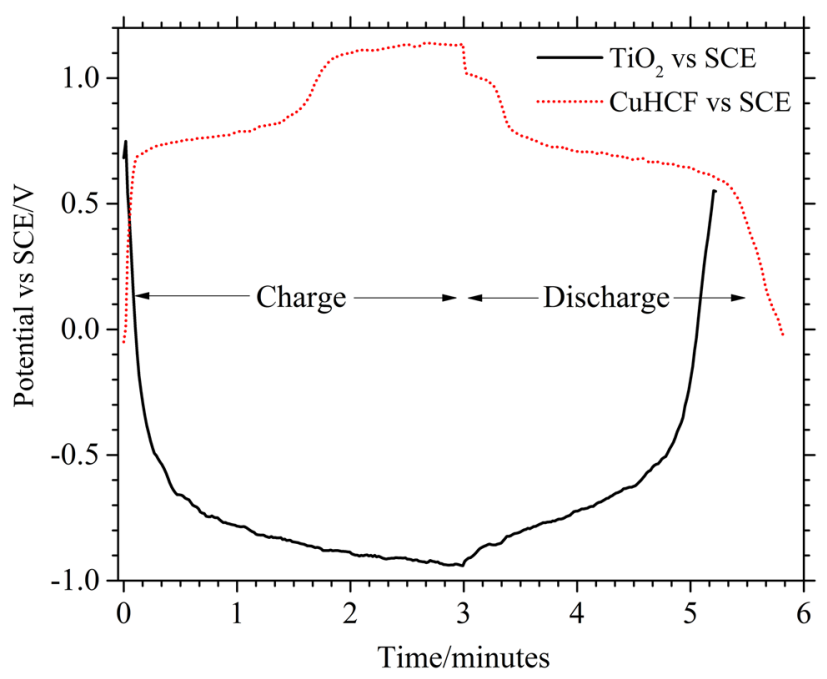

Fig. 6 Top (red-dotted): typical voltage profile, vs. SCE, of a $\mathrm{CuHCF}$ electrode under cycling at $1000 \mathrm{~mA} \mathrm{~g}^{-1}$. Bottom (black-solid): typical voltage profile, vs. SCE, of a $\mathrm{TiO}_{2}$ electrode under cycling at $333 \mathrm{~mA}$ $\mathrm{g}^{-1}$. A $1 \mathrm{~mol} \mathrm{dm}^{-3} \mathrm{AlCl}_{3} / 1 \mathrm{~mol} \mathrm{dm}^{-3} \mathrm{KCl}$ electrolyte was used in both cells. (Color figure online) 
CuHCF [5]. The more positive voltage profile in Fig. 6 corresponds to $\mathrm{CuHCF}$ during a typical cycle. During charge, two plateaus are visible at 0.75 and $1.1 \mathrm{~V}$, each accounting for approximately half of the charge capacity. Similarly, two discharge plateaus are visible at 0.98 and $0.65 \mathrm{~V}$, although the first discharge plateau accounts for only $7 \%$ of the discharge capacity. The nature of the two plateaus is not yet understood. The $0.1 \mathrm{~V}$ hysteresis between final charge voltage and initial discharge voltage suggests that the rate capability of CuHCF may be inferior to $\mathrm{TiO}_{2}$, although coulombic efficiency is clearly superior. The $<100 \%$ efficiency is attributed to side reactions such as $\mathrm{O}_{2}$ evolution.

A balanced cell ( $85 \mathrm{mg} \mathrm{TiO}_{2}$ vs. $38 \mathrm{mg} \mathrm{CuHCF}$ ) was cycled nearly 2000 times at a current corresponding to a $20 \mathrm{C}$ rate. The efficiencies and discharge capacity throughout cycling are shown in Fig. 7 with the evolution of the voltage profile given in Fig. 8. A maximum capacity, calculated from the combined mass of electrodes, of circa $10.6 \mathrm{~mA} \mathrm{~h}$ $\mathrm{g}^{-1}$ remained above $10 \mathrm{~mA} \mathrm{~h} \mathrm{~g}^{-1}$ until the 1814 th cycle. An average discharge voltage which ranged between $1.49 \mathrm{~V}$ at cycle 100 and $1.46 \mathrm{~V}$ at cycle 1750 gives the cell an energy density of ca. $15 \mathrm{~mW} \mathrm{~h} \mathrm{~g}^{-1}$. An initial coulombic efficiency of $96 \%$ was still above $90 \%$ by the 1900th cycle; energy efficiency decreased from $\sim 80$ to $70 \%$ at cycle number 1778 . Therefore, while capacity and energy density remain low, a cell with good voltage, cycle life, efficiency and rate capability has been demonstrated.

A 2-cell aqueous Al-ion battery is also demonstrated using a bipolar electrode. The voltage vs. time profile is compared to a single cell in Fig. 9. The charge and voltage efficiencies are comparable. Cycling at a $10 \mathrm{C}$ rate, the charge voltage increases steadily from circa 2.0 to $3.5 \mathrm{~V}$, at which point there is a more rapid increase in voltage to

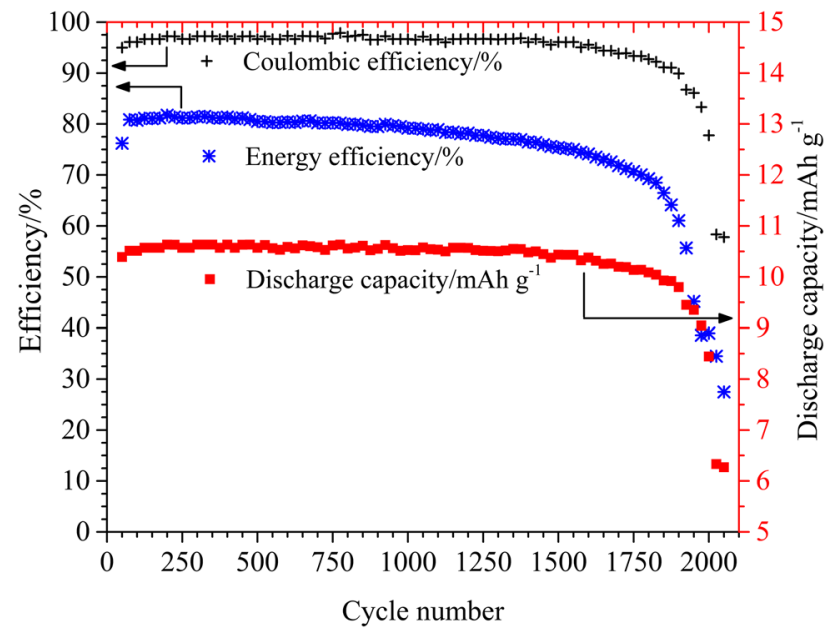

Fig. 7 Performance of a balanced Al-ion cell consisting of $\mathrm{TiO}_{2}$ negative electrode, $\mathrm{CuHCF}$ positive electrode and $1 \mathrm{~mol} \mathrm{dm}^{-3} \mathrm{AlCl}_{3} / \mathrm{mol}$ $\mathrm{dm}^{-3} \mathrm{KCl}$ electrolyte. A 20C charge/discharge rate was used

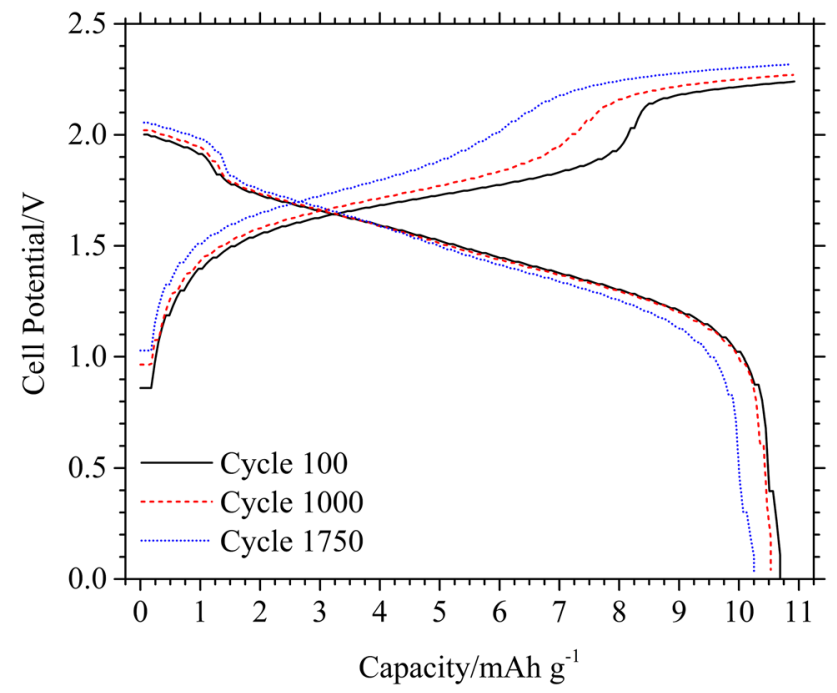

Fig. 8 Evolution of the charge/discharge profile of the aqueous Al-ion cell under extended cycling at $20 \mathrm{C}$ in $1 \mathrm{~mol} \mathrm{dm}^{-3} \mathrm{AlCl}_{3} / 1 \mathrm{~mol} \mathrm{dm}^{-3}$ $\mathrm{KCl}$

$4.1 \mathrm{~V}$ before a further steady increase to $4.5 \mathrm{~V}$ at the end of charge. During discharge, the voltage decreases steadily from 4.0 to $3.7 \mathrm{~V}$, at which point there is a rapid drop-off to $3.4 \mathrm{~V}$ followed by a more steady decline to $2.0 \mathrm{~V}$ at the end of discharge. From Fig. 5, the two-voltage stages are associated with the CuHCF positive electrode. An average discharge voltage of $2.93 \mathrm{~V}$ was achieved, giving the battery an energy density of $14.8 \mathrm{~mW} \mathrm{~h} \mathrm{~g}^{-1}$ according to total mass of active material in both electrodes.

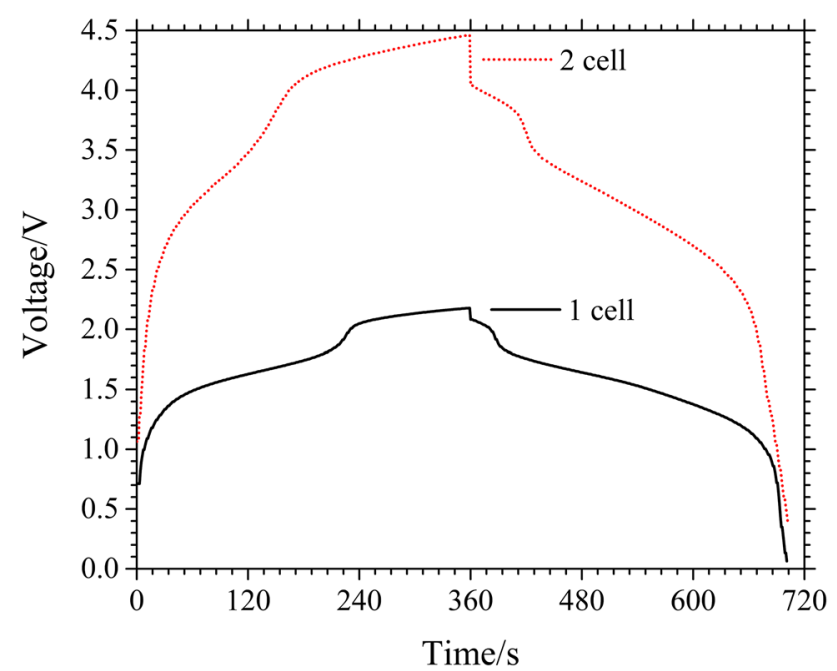

Fig. 9 Typical profile of a 1-cell and 2-cell Al-ion battery cycled at a $10 \mathrm{C}$ charge/discharge rate in $1 \mathrm{~mol} \mathrm{dm}^{-3} \mathrm{AlCl}_{3} / 1 \mathrm{~mol} \mathrm{dm}^{-3} \mathrm{KCl}$ electrolyte 


\section{Conclusion}

The first multi-cell battery based on aqueous aluminium ion chemistry is described. The battery is based on anatase $\left(\mathrm{TiO}_{2}\right)$ nanopowder, $\mathrm{CuHCF}$ and aqueous $\mathrm{Al}^{3+} / \mathrm{K}^{+}$electrolyte, which are all widely available, cheap and non-toxic materials, providing advantages over current Li-ion and $\mathrm{Pb}$-acid systems. Although the specific energy is relatively low, ca. $15 \mathrm{mWh} \mathrm{g}^{-1}$ active material (combined positive and negative materials), a high charge and discharge rate of $20 \mathrm{C}$ is achievable. At the $20 \mathrm{C}$ rate, the energy efficiency of the cell remained above $70 \%$ for over 1750 cycles, with only a $7 \%$ capacity fade, demonstrating the longevity of the cell. The low specific energy is caused by the $\mathrm{TiO}_{2}$ anode; the capacity of CuHCF is c.a. $50 \mathrm{mAh} \mathrm{g}^{-1}$ at a current density of $333 \mathrm{~mA} \mathrm{~g}^{-1}$.

The charge storage capacity of $\mathrm{TiO}_{2}$ was shown to be due to the presence of $\mathrm{Al}^{3+}$ rather than the $\mathrm{H}^{+}$present in the acidic electrolyte. However, the slight shift in neutron diffraction parameters is not sufficient to ascertain whether the main mechanism of charge storage is via $\mathrm{Al}^{3+}$ intercalation or a surface adsorption reaction. Further work on elucidating the mechanism could allow the cell capacity to be increased and the active materials to be tailored, for example towards high surface area materials for a surface process or doped materials for intercalation. Self-discharge exhibited by the $\mathrm{TiO}_{2}$ electrode, most likely due to the presence of dissolved oxygen, needs to be minimised and investigated further.

Acknowledgements This project has received funding from the European Union's Horizon 2020 research and innovation programme under rant agreement No. 646286. The authors would also like to thank Martin-Owen Jones at STFC for his assistance in interpreting the GEM neutron diffraction data obtained at ISIS.

Open Access This article is distributed under the terms of the Creative Commons Attribution 4.0 International License (http://creativeco mmons.org/licenses/by/4.0/), which permits unrestricted use, distribution, and reproduction in any medium, provided you give appropriate credit to the original author(s) and the source, provide a link to the Creative Commons license, and indicate if changes were made.

\section{References}

1. BP (2015) BP statistical review of world energy 2015

2. EPRI (2010) Electricity energy storage options: a white paper on applications, costs and benefits. EPRI, Palo Alto

3. Wang. D-Y et al (2017) Advanced rechargeable aluminium ion battery with a high-quality natural graphite cathode. Nat Commun 8:14283
4. Wang $\mathrm{S}$ et al (2017) High-performance aluminum-ion battery with CuS@C microsphere composite cathode. ACS Nano 11:469-477

5. Angell M, Pan C-J, Rong Y, Yuan C, Lin M-C, Hwang B-J, Dai H (2016) High Coulombic efficiency aluminum-ion battery using an $\mathrm{AlCl} 3$-urea ionic liquid analog electrolyte. PNAS 114, 5:834-839

6. Lin M-C, Gong M, Lu B, YingpengWu D-Y, Wang M, Guan M, Angell C, Chen J, Yang B-J, Hwang H, Dai (2015) An ultrafast rechargeable aluminium-ion battery. Nature 520:325-328

7. Sun H, Wang W, Yu Z, Yuan Y, Wang S, Jiao S (2015) A new aluminium-ion battery with high voltage, high safety and low cost. Chem Commun 51:11892-11895

8. Wang H, Bai Y, Chen S, Luo X, Wu C, Wu F, Lu J (2015) Binderfree $\mathrm{V}_{2} \mathrm{O}_{5}$ cathode for greener rechargeable aluminum battery. Appl Matter Interfaces 7:80-84

9. Geng L, Lv G, Guo XX,J (2015) Reversible electrochemical intercalation of aluminum in Mo6S8. Chem Mater 27:4926-4929

10. Hudak N (2014) Chloroaluminate-doped conducting polymers as positive electrodes in rechargeable aluminum batteries. J Phys Chem 118:5203-5215

11. He YJ, Peng JF, Chu W, Li YZ, Tong DG (2014) Black mesoporous anatase $\mathrm{TiO}_{2}$ nanoleaves: a high capacity and high rate anode for aqueous Al-ion batteries. J Mater Chem A 2:1721-1731

12. Liu S, Pan GL, Li GR, Gao XP (2015) Copper hexacyanoferrate nanoparticles as cathode material for aqueous Al-ion batteries. J Mater Chem 3:959-962

13. Reed LD, Ortiz SN, Xiong M, Menke EJ (2015) A rechargeable aluminum-ion battery utilizing a copper hexacyanoferrate cathode in an organic electrolyte. Chem Commun 51:14397-14400

14. Pasta M, Wessells CD, Liu N, Nelson J, McDowell MT, Huggins RA, Toney MF, Cui Y (2015) Full open-framework batteries for stationary energy storage. Nat Commun. https://doi.org/10.1038/ ncomms 4007

15. Trócoli DR, La Mantia DF (2015) An aqueous zinc-ion battery based on copper hexacyanoferrate. ChemSusChem 8:481-485

16. Jia Z, Wang B, Wang Y (2015) Copper hexacyanoferrate with a well-defined open framework as a positive electrode for aqueous zinc ion batteries. Mater Chem Phys 149-150:601-606

17. Wessells CD, Peddada SV, McDowell MT (2012) The effect of insertion species on nanostructured open. J Electrochem Soc 159(2):98-103

18. Kazazi M, Abdollahi P, Mirzaei-Moghadam M (2017) High surface area $\mathrm{TiO}_{2}$ nanospheres as a high-rate anode material for aqueous aluminium-ion batteries. Solid State Ionics 300:32-27

19. Gonz'alez JR, Nacimiento MCF, Alc'antar R, Lavel P, Tirado aJL (2016) Reversible intercalation of aluminium into vanadium pentoxide xerogel for aqueous rechargeable batteries. RSC Adv 6:62157-62164

20. Liu Y, Wu SSQ, Lu Z, Liu K, Liu H (2014) The electrochemical behavior of $\mathrm{Cl}^{-}$assisted $\mathrm{Al}^{3+}$ insertion intotitanium dioxide nanotube arrays in aqueous solution for aluminumion batteries. Electrochim Acta 143:340-346

21. Liu S, Hu JJ, Yan NF, Pan GL, Li GR, Gao XP (2012) Aluminum storage behavior of anatase $\mathrm{TiO}_{2}$ nanotube arrays in aqueous solution for aluminum ion batteries. Energy Environ Sci 5:9743-9746 